EISSN: 2706 -7947 ISSN: 2077- 4613

DOI: 10.36632/mejas/2021.11.2.41

Journal homepage: www.curresweb.com

Pages: 503-513

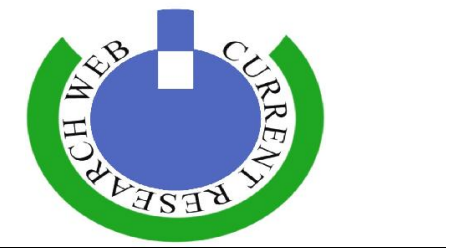

\title{
Preparation and Evaluation High-Quality Gluten-Free Flat Bread I: Effect of Using Improvers on the Chemical and Physical Properties
}

\author{
Manal H. Abd-Elkader ${ }^{1}$, Nahed S. Yousef ${ }^{2}$ and Samah A.T. Abu El-maaty ${ }^{2}$ \\ ${ }^{1}$ Bread and Pastries Research Dept., Food Technology Research Institute, Agricultural Research \\ Center, Giza, Egypt. \\ ${ }^{2}$ Food Science and Technology Dept., Faculty of Home Economics, Al-Azhar University, Egypt. \\ Received: 25 April $2021 \quad$ Accepted: 30 May $2021 \quad$ Published: 10 June 2021
}

\begin{abstract}
The vision to eat free gluten bread similar to wheat bread is still a dream to free gluten patients. This research focused on finding and implementing gluten for developing gluten-free high-quality commercial bread for celiac patients. Gluten-free flour from different sources, such as rice flour $(\mathrm{R})$, corn flour $(\mathrm{C})$, millet powder $(\mathrm{M})$, flax seeds powder $(\mathrm{F})$, rice bran $(\mathrm{B})$, and potato powder $(\mathrm{P})$, and improvers such as okra, guar gum, and xanthan gum, whey protein and white egg were examined. These ingredients were trialed in different combinations and compositions to produce a dough having the ability to trap the carbon dioxide gas during proofing and baking to get high-quality gluten-free flatbread. A specific combination of FRP, MRP, and BCRP was made. The ingredients and their compositions were manipulated according to the outcomes of the trials and their contribution to the formulations. The chemical composition of the tested gluten-free flour and the physical properties of flatbread were determined. The results presented that, high fiber, protein, and fat content were found in flaxseed powder and okra improver, while, the high ash content found in rice bran. The high viscosity and water absorption capacity (WAC) values were found in gluten-free bread formula (MRP, FRP, and BCRP) with okra improver followed by xanthan \& guar gum, whey protein, and white egg. On the reverse, the baking weight loss was lower in MRP, FRP, and BCRP of gluten-free formula with okra improver flowed by xanthan \& guar gum. While the improvers whey protein and white egg had the high baking weight loss in the same bread samples. The results showed that adding okra at different levels led to increase the viscosity and water absorption capacity and reduced baking loss in gluten free flatbread compared to the other used improvers. rocks represented by lower Nubia sandstones, Natash volcanic and Upper Nubia sandstones.
\end{abstract}

Keywords: Gluten-free, celiac disease, flat bread, improvers, hydrocolloids

\section{Introduction}

Without a healthy intestinal lining, the body cannot absorb the nutrients it needs. Delayed growth and nutrient deficiencies can result and may lead to conditions such as anemia and osteoporosis. The celiac disease occurs when the body's natural defense system reacts to gluten by attacking the lining of the small intestine. Other serious health problems may include diabetes, autoimmune thyroid disease and intestinal cancers. (Kahlon and Chiu, 2012).

Nowadays, the world is experiencing an increased demand for gluten-free products associated with the high prevalence of gluten-related disorders. Therefore, it is necessary to standardize the process of gluten-free bread production and labeling, as well as to improve the nutritional characteristics of these products, aiming the give accurate information to consumers and provide a healthier product beyond the sensory characteristics (Romão et al., 2020).

Baking without gluten is a big challenge, owing to gluten-free flours' inability to form cohesive and elastic dough. Gluten in wheat dough is a plastic-elastic substance consisting give dough elastic

Corresponding Author: Manal H. Abd-Elkader, Bread and Pastries Research Dept., Food Technology Research Institute, Agricultural Research Center, Giza, Egypt.

E-mail: haggag_eg@yahoo.com 
and extensible properties able to develop good quality bakery products. The unique characteristics of wheat gluten and lack it led hard to find raw materials, starch, additives, or ingredients that can entirely replace it (Pszczola, 2012). The using alternative ingredients including starches fiber sources (Tsatsaragkou et al., 2014 and El-Khoury et al., 2018), gluten-free flours (Lemos et al., 2012; Wronkowska et al., 2013), hydrocolloids is play a role as an improvement in dough rheological characteristics and sensory effects of gluten in gluten-free products.(Sabanis and Tzia, 2011; Nicolaeet al., 2016; El-Khoury et al., 2018).

Flat bread is simple bread baked and produced in both the bakeries and home in the Middle East made from flattened dough of flour, salt, water, yeast and other optional components. (Al-Dmoor, 2012). Gluten-free breads are technologically poor with low specific volume; crumb softness and higher staling rate compared to wheat bread owing to the lack of gluten structure (Gallagher et al., 2003 and Arendt et al., 2007).Bread made of corn flour (100\%) required the largest amount of water addition $(120 \%)$; better quality of bread made of rice flour $(100 \%)$ was characterized by the lowest amount of water addition (80\%) (Różyło et al., 2015).

Maize flour is among the preferred ingredients in the preparation of gluten-free products (Schober et al., 2008 and Mastromatteo et al., 2011). Even though corn flour supplies many micro-and macro nutrients, amounts of some essential nutrients are inadequate. Therefore, consumption of these products contributes only small amounts of proteins, minerals and dietary fibers, thus increasing the risk of nutritional deficiencies associated with celiac disease.

Dough and bread formulated with millet flour presented low specific volume and high bread hardness compared to the control (Sayed et al., 2016). Millet does not contain gluten and is known for its low carbohydrate concentration and low glycemic index (Singh et al., 2010 and Suma and Urooj, 2014), The acceptability of the foods developed with millet flour, such as biscuit dough and breads, is reported to be very good (Saha et al., 2011 and Schoenlechner et al., 2013).

Potato flour has become the most viable value-added product due to its versatility as a thickener and color or flavor improver (Yadav et al., 2016).Potatoes contain good quality edible grade protein, dietary fiber, several minerals and trace elements, essential vitamins and little or negligible fat (Misra and Kulshrestha, 2003).

Stabilized rice bran by heating represents good sources for nutrients such as fat, protein, fiber, minerals, vitamins and antioxidants. Most of nutrients were concentrated in fine fractions (lower than $400 \mu \mathrm{m})$. These fractions can be used to prepare Kahk El-Eid and Petit-four with nutritive advantage since Egyptians consume large amounts in their festival. (Abd El-Kader, 2014).

Ancient whole grains make nutritious gluten-free flatbreads that are simple to make at home as well as in a commercial production. It can be every day staple for all families. It is low in fat, calories, good source of protein, fiber and minerals (Kahlon and Chiu, 2014).

Dietary fiber evading digestion, absorption, and hydrolysis, dietary fiber is also involved in increasing fecal bulk, stimulating colonic fermentation, and reducing pre-prandial cholesterol levels and levels of postprandial blood glucose in the body of the organism (Gomez et al., 2010). The technological properties of dietary fiber in bread making are occasioned by its water-holding capacity which prevents the bread from staling, which could extend the shelf-life of the product.

Flaxseed is an excellent source of nutrients including protein, soluble and insoluble dietary fiber as well as omega-3 fatty acids. The flaxseed can be used as a whole or it can be incorporated in other foods including bakery products. The flaxseed proteins can enhance the biological parameters of bread and unleavened flat bread (chapattis). The addition of flaxseed to wheat flour can also contribute towards several health benefits and can serve as a low-cost treatment for many diseases, e.g. diabetes, hypercholesterolemia and cardiovascular complications. The incorporation of flaxseed into the diet can improve taste in regularly consumed dishes. The reddish brown flaxseed grains have a pleasant flavor and taste resembling nuts, and they are easily incorporated in different products. The baked products can be supplemented with whole flaxseed grains to achieve an attractive and appealing form which enhances the texture of the final product (Hussain et al., 2013).

Recently, many studies have focused their research on improving the quality of gluten-free bread. Natural ingredients obtained from plants and fruits can help to correct the lack of certain nutrients in these products. In this context, Bourekoua et al., (2021) used acerola fruit to improve both rheological and nutritional properties of gluten-free bread. Also Li et al., 2017 and Shahzad et al., (2019) used okra hydrocolloid to alter the enthalpy of starch gelatinization, reducing the firmness of the dough and 
delaying the retrogradation which reduces syneresis. Okra offers a consistent hydrocolloid when cooked; and it is usually added to other foods that need improvement in consistency (Noorlaila et al., 2015). Okra hydrocolloid is extracted in water; it results in a highly viscose solution with slimy texture and has proven to strengthen soft wheat dough (Ramadas and Tharanathan, 1987).

The majority of gluten-free products described in the literature are made from native and modified starches blended with different hydrocolloids or other improvers, with the aim of improving dough rheological properties, bread appearance and volume, and crumb structure (Matos and Rosell, 2015). Recently, a significant increase in demand for better-quality products has increased research into their development (Arendt and Dal Bello, 2008). The most noteworthy approaches are based on: the use of gluten-free flours (pseudo-cereals, maize, rice, etc.), and naturally gluten-free sources of starch (potato, maize, rice, etc.); the addition of protein from other production chains (egg, dairy ingredients, soya, etc.); the use of alternative sources of protein to strengthen dough (insects and legumes); and the addition of gums, hydrocolloids, emulsifiers, and enzymes as improvers.

The aim of this study was to develop gluten-free flatbread with similar quality characteristics to that of standard flatbread in the local market of Egypt. Within this constraint, the dough has to be produced with handling and molding properties similar to those of conventional wheat flour bread.

\section{Materials and Methods}

\subsection{Materials}

\subsubsection{The raw materials gluten-free flour:}

White rice flour, corn flour and potato powder were purchased from Tiba Food Industries Company, at Burj Al Arab Alexandria, Egypt.Stabilized rice bran obtained from Agricultural Engineering Research institute. While, Pearl millet and flax seeds powder were obtained from Forage Crops Research Department, Field Crops Institute, Agricultural Research Center, Giza, Egypt.

Fresh okra was obtained from the local market of Mit Ghamr, El-Mansoura City, El Dakahlia Governorate, Egypt.

Xanthan and guar gums were obtained from Free Gluten Center, Food Technology Research Institute, Agricultural Research Center, Giza, Egypt. While, whey protein powder and white egg powder were purchased from the whole sale market of Bab El Bahr, Cairo, Egypt.

\subsection{Methods}

\subsubsection{Preparation of okra powder}

Fresh okra fruits were washed manually then dried in sun for three days (at June 2018). The sun dried okra put in oven for 4 hours at $50^{\circ} \mathrm{C}$ (Kouassi et al., 2013), then milled by roller milling Quadrumat junior mill (Brabender-made in Germany) and passed through sieve $160 \mu \mathrm{m}$. The dried okra powder was collected and packing in polyethylene bags until use.

\subsubsection{Preparation of pearl millet and flax seeds}

Pearl millet and flax seeds were cleaned and milling in Quadrumat junior mill to obtain hall meal fine powder.

\subsubsection{Formula of gluten-free flat bread dough samples}

The best and economic formulas were chosen after many trials to obtain suitable handling and processing properties dough with high-quality texture and flavor gluten-free loaf properties close likeness to those of conventional wheat flour bread.

Table 1: The formula of gluten-free flat bread samples (g)

\begin{tabular}{|l|c|c|c|c|c|c|}
\hline Sample & $\begin{array}{c}\text { Corn } \\
\text { flour }\end{array}$ & $\begin{array}{c}\text { Rice } \\
\text { flour }\end{array}$ & $\begin{array}{c}\text { Potato } \\
\text { powder }\end{array}$ & $\begin{array}{c}\text { Millet } \\
\text { powder }\end{array}$ & $\begin{array}{c}\text { Flax seeds } \\
\text { powder }\end{array}$ & $\begin{array}{c}\text { Rice } \\
\text { bran }\end{array}$ \\
\hline MRP & - & 75 & 50 & 25 & - & - \\
\hline FRP & - & 75 & 50 & - & 25 & - \\
\hline BCRP & 30 & 50 & 50 & - & - & 20 \\
\hline
\end{tabular}


The basic gluten-free flatbread formula (150 g flour basis) contained $1 \%$ instant yeast and $1 \%$ salt. White egg improver was added as 2, 3, and $4 \mathrm{~g} / 150 \mathrm{~g}$ flour basis. While okra and whey protein improvers were added as 3, 5 and $7 \mathrm{~g} / 150 \mathrm{~g}$ flour basis for all formula. Xanthan and guar gum blends were added by mixing an equal amount of each gum for all formulas at $(0.4+0.4 ; 0.6+0.6 ; 0.8+0.8 \mathrm{~g}$ $150 \mathrm{~g}$ flour basis). The dough of flatbread prepared according to the methods described in (Maleki and Daghir, 1967) by dissolving $1 \%$ instant yeast in $10 \mathrm{ml}$ water at $35 \pm 1{ }^{\circ} \mathrm{C}$. This dispersion was added to the dry recipe and then added $165-270 \mathrm{ml}$ water at $37 \pm 1^{\circ} \mathrm{C}$ for different formula dough, then mixed and kneading well with hand for 5 min.

Dough samples fermented for $60 \mathrm{~min}$ at $25^{\circ} \mathrm{C}$. The fermented dough was divided and rounded into balls. The balls were sheets for 2-4 mm thickness to form the bread and then fermented for $20 \mathrm{~min}$ at room temperature. The bread was carried out in a gas oven at $400{ }^{\circ} \mathrm{C}$ for $30-50$ seconds. After baking, the bread was cooled at room temperature for 5-10 min. Samples were packed in low-density polyethylene and stored $48 \mathrm{~h}$ at room temperature.

\subsection{Analytical methods}

\subsubsection{Chemical composition}

The moisture, protein, ether extract, crud fiber and ash content were determined according to the official method of A.O.A.C. (2010).

\subsubsection{Determination of water absorption capacity}

The water absorption capacity of the flours was determined by the method of Sosulski et al., (1976). Water absorption was examined as percent water bound per gram flour.

\subsubsection{Determination of viscosity}

The viscosity of tested flour samples were measured using apparent viscosity of flour and measured directly using Brookfield Digital Rheometer, Model DVIII Ultra, by using HA-05 spindle for rheological measurements (Brookfield Manual, 1998).

\subsection{Physical properties of gluten-free flat bread}

\subsubsection{Bread weight loss}

The weight loss after baking bread samples were determined according to the methods described in following equation (Majzoobi et al., 2011).

$$
\% \text { Baking weight loss }=\frac{\text { Weight of bread dough }- \text { Weight of bread }}{\text { Weight of bread dough }} \times 100
$$

\subsubsection{Weight of up layer and down layer}

The gluten-free flat bread samples were weight as whole loaf $(\mathrm{g})$, upper layers and down layersafter cooling at room temperature according to the method of Zahran et al., (2005).

\subsection{Statistical Analysis}

The data were analyzed according to Steel and Torrie (1980). Analyses were performed with SPSS program (SPSS Inc., Chicgo, IL. USA) the data were analyzed by one-way analysis of variance (ANOVA). Means separation was performed by Duncan's multiple range tests. Differences at $p \leq 0.05$ were considered as significant (Armitage et al., 1987).

\section{Results and Discussion}

\subsection{Chemical composition of raw materials}

Data in Table (2) illustrated that the chemical composition of tested gluten-free flour and improvers. There were significant differences between all tested materials in moisture, protein, fat, ash, and fiber. Rice and potato powder had higher moisture content (12.8 and $12.5 \%$, respectively) than other tested gluten-free flour. On the other hand, rice and potato powder had the lowest protein contents (7.93 and 7.46\%, respectively). These results were in agreement with Nascimento et al., (2014) who reported that rice flour contains $13.1 \%$ moisture and $7.1 \%$ protein, and Ijah et al., (2014) reported that 
potato flour had contained 7\% protein. In contrast, flax seeds had the lowest moisture content $(7.25 \%)$. Flax seeds are characterized by their high content of protein (19.07\%), fat (39.11\%), and fiber (27.18\%). The previous research reported that, protein, fat, and fiber content were $20 \%, 41.1$ and $27.7 \%$, respectively in flax seeds (Morris, 2003 and Singh et al., 2011).

Ash content of rice bran was $9.19 \%$, which is the highest value among the tested gluten-free flour. Abd El-Kader (2014) found that the ash content in wholemeal rice bran was $7.55 \%$ and in their fractions was between $6.69 \%$ and $8.24 \%$ on a dry weight basis. Table 2 also showed that rice flour had the lowest ash content $(0.73 \%)$. Aly and Seleem (2015) found that ash content in rice flour was $0.93 \%$.

Millet powder had moderated amounts of ash, protein, fat, and fiber content which were 2.24, $12.44,5.85$, and $4.55 \%$, respectively. These results agree with data showed by Burton et al., (1972) who found that pearl millet is equal or superior to the grain of wheat, corn, sorghum, and rice in protein and oil content. Singh and Srivastava (2006) analyzed 16 finger millet varieties and found out that protein ranged from 4.88 to $15.58 \%$ with a mean value of $9.728 \%$. Sridhar and Lakshminarayana (1994) reported the total lipid content in finger millet to be $5.2 \%$.

Table 2: Chemical composition of raw materials on dry weight basis

\begin{tabular}{|c|c|c|c|c|c|}
\hline Tested samples & Moisture (\%) & Ash (\%) & Protein (\%) & Fat (\%) & Fiber (\%) \\
\hline \multicolumn{6}{|c|}{ Tested gluten-free flours } \\
\hline Corn & $11.23^{\mathrm{c}}$ & $1.92^{\mathrm{c}}$ & $9.32^{\mathrm{d}}$ & $4.99^{\mathrm{d}}$ & $2.86^{\mathrm{cd}}$ \\
\hline Rice & $12.80^{\mathrm{a}}$ & $0.73^{\mathrm{d}}$ & $7.93^{\mathrm{e}}$ & $4.25^{\mathrm{de}}$ & $1.43^{\mathrm{d}}$ \\
\hline Potato & $12.15^{\mathrm{b}}$ & $3.45^{\mathrm{b}}$ & $7.46^{\mathrm{e}}$ & $2.80^{\mathrm{f}}$ & $3.55^{\mathrm{c}}$ \\
\hline Rice bran & $8.34^{\mathrm{e}}$ & $9.19^{\mathrm{a}}$ & $12.55^{\mathrm{b}}$ & $9.24^{b}$ & $7.31^{\mathrm{b}}$ \\
\hline Millet & $10.27^{\mathrm{d}}$ & $2.24^{\mathrm{c}}$ & $12.44^{\mathrm{b}}$ & $5.85^{\mathrm{c}}$ & $4.55^{\mathrm{c}}$ \\
\hline Flax seeds & $7.25^{\mathrm{f}}$ & $3.19^{\mathrm{b}}$ & $19.07^{\mathrm{a}}$ & $39.11^{\mathrm{a}}$ & $27.18^{\mathrm{a}}$ \\
\hline \multicolumn{6}{|c|}{ Tested Improvers } \\
\hline Okra & $9.02^{\mathrm{A}}$ & $5.14^{\mathrm{B}}$ & $19.33^{\mathrm{C}}$ & $13.60^{\mathrm{A}}$ & $34.67^{\mathrm{A}}$ \\
\hline Guar gum & $6.14^{\mathrm{C}}$ & $1.32^{\mathrm{C}}$ & $4.39^{\mathrm{D}}$ & $0.70^{\mathrm{BC}}$ & $6.10^{\mathrm{B}}$ \\
\hline Xanthan gum & $7.84^{\mathrm{B}}$ & $6.59^{\mathrm{A}}$ & $0.60^{\mathrm{E}}$ & $0.87^{\mathrm{B}}$ & $3.33^{\mathrm{C}}$ \\
\hline White egg & $4.16^{\mathrm{D}}$ & $0.97^{\mathrm{C}}$ & $79.93^{\mathrm{B}}$ & $0.30^{\mathrm{C}}$ & $1.23^{\mathrm{D}}$ \\
\hline Whey protein & $5.33^{\mathrm{C}}$ & $1.10^{\mathrm{C}}$ & $83.83^{\mathrm{A}}$ & $0.53^{\mathrm{BC}}$ & $2.54^{\mathrm{C}}$ \\
\hline
\end{tabular}

In a column, means having the same superscript letters are not significantly different at $5 \%$ level. Small letters for tested gluten-free flour, capital letters for tested improvers.

The chemical composition of tested improvers in Table (2) showed that the okra had a higher content of moisture $(9.02 \%)$, fat (13.6\%), and fiber (34.67\%) than other tested improvers. In previous research, it was found that whole okra flour had $14.73 \%$ fat and $36.9 \%$ fiber content (Adelakun and Oyelade, 2011).

Xanthan gum contained $6.59 \%$ ash which is the highest value followed by okra $(5.14 \%)$. KiWon et al., (2006) stated that ash in xanthan gum ranged between 7-12\%, meanwhile, protein ranged between $8-15 \%$. Whey protein and white egg reported 83.83 and $79.93 \%$ protein, respectively. Meanwhile, xanthan gum and guar gum had 0.6 and $4.39 \%$ protein, respectively. According to Chudzikowski (1971) study, protein in guar gum ranged between 5-6\%.

Protein in tested improvers reported in the previous research to be $20.5 \%$ in okra (Adelakun and Oyelade, 2011), 25-89\% in whey protein (Marshall, 2004), 0.3-1\% in xanthan gum (Garcia-Ochoa et al., 2000), 5-6\% guar gum (Mudgil et al., 2014) and 88.23-97.52\% in white egg (Sze et al., 2018).

\subsection{Effect of using improvers on dough viscosity}

The peak viscosity is the maximum viscosity attained by starch during gelatinization. It indicates the water-binding capacity of the starch granules. This often correlates with final product quality. The small amount of water from dough prevents intermolecular interactions between the ingredients and produces a water-binding competition between ingredients (De la Hera et al., 2014).

The lower peak viscosity was found in all bread flour formulas prepared with different concentrations of white egg $(2,3$, and $4 \mathrm{~g} / 150 \mathrm{~g}$ formula). The whey protein recorded the second grade 
of lower viscosity between improvers. The white egg improver had viscosity ranged between $19 \mathrm{cP}$ to $40 \mathrm{cP}$ with 2-4 $\mathrm{g}$ white egg when used as improver due for gluten-free flatbread. Whey protein as improver from 3-7g in gluten-free flatbread had beak viscosity ranged between $25 \mathrm{cP}$ to $66 \mathrm{cP}$. On the other side, the highest peak viscosity was in bread flour formula prepared with okra powder followed by xanthan and guar gum blends (Table 3). These results agree with Alamri (2014) who found that okra extract could affect the viscoelastic properties of the flour and cause the material to exhibit weaker viscoelastic behavior.

Viscosity ranged between $83 \mathrm{cP}$ and $185 \mathrm{cP}$ when used okra as an improver with 3 and $7 \mathrm{~g}$ okra in gluten-free flatbread. Meanwhile, viscosity ranged between $73 \mathrm{cP}$ and $136 \mathrm{cP}$ using the xanthan and guar gum mixture at $0.8 \mathrm{~g}$ to $1.6 \mathrm{~g}$.

When hydrocolloids interact with water during the bread-making process, they produce a gel network that serves to rise dough viscosity and strengthen the boundaries of expanding cells, increasing gas retention capability during proofing and baking, improving bread volume, structure, texture, and appearance (Anton and Artfield, 2008; Mastromatteo et al., 2012 and Miñarro et al., 2012).

Table 3: Effect of using different levels of improvers on gluten-free dough viscosity, water absorption capacity and weight loss of baking

\begin{tabular}{|c|c|c|c|c|c|c|c|c|c|}
\hline \multirow[t]{2}{*}{$\begin{array}{l}\text { Improvers } \\
\text { levels (g) }\end{array}$} & \multicolumn{3}{|c|}{$\begin{array}{l}\text { Viscosity } \\
\text { (cP) }\end{array}$} & \multicolumn{3}{|c|}{$\begin{array}{c}\text { Water absorption capacity } \\
(\%)\end{array}$} & \multicolumn{3}{|c|}{$\begin{array}{c}\text { Weight loss of baking } \\
(\%)\end{array}$} \\
\hline & MRP & FRP & BCRP & MRP & FRP & BCRP & MRP & FRP & BCRP \\
\hline \multicolumn{10}{|c|}{ Okra } \\
\hline 3 & 83 & 95 & 86 & $266.00^{\mathrm{b}}$ & $265.00^{\mathrm{b}}$ & $266.00^{\mathrm{b}}$ & $33.52^{\mathrm{e}}$ & $31.38^{\mathrm{e}}$ & $32.20^{\mathrm{e}}$ \\
\hline 5 & 160 & 173 & 115 & $264.00^{\mathrm{c}}$ & $266.00^{\mathrm{b}}$ & $266.00^{\mathrm{b}}$ & $30.19^{\mathrm{f}}$ & $29.90^{\mathrm{f}}$ & $28.99^{\mathrm{h}}$ \\
\hline 7 & 185 & 178 & 135 & $271.36^{\mathrm{a}}$ & $268.00^{\mathrm{a}}$ & $270.34^{\mathrm{a}}$ & $25.82^{\mathrm{h}}$ & $26.12^{\mathrm{h}}$ & $25.88^{\mathrm{j}}$ \\
\hline \multicolumn{10}{|c|}{ Xanthan \& guar gum } \\
\hline 0.8 & 75 & 73 & 75 & $194.67^{\mathrm{e}}$ & $195.33^{\mathrm{d}}$ & $194.63^{\mathrm{e}}$ & $35.59^{c}$ & $34.27^{\mathrm{c}}$ & $30.07^{\mathrm{g}}$ \\
\hline 1.2 & 105 & 97 & 108 & $196.34^{\mathrm{e}}$ & $196.00^{\mathrm{d}}$ & $196.35^{\mathrm{d}}$ & $32.95^{\mathrm{e}}$ & $32.63^{d}$ & $28.52^{\mathrm{h}}$ \\
\hline 1.6 & 136 & 117 & 129 & $200.00^{\mathrm{d}}$ & $199.67^{c}$ & $200.33^{\mathrm{c}}$ & $28.85^{\mathrm{g}}$ & $27.38^{\mathrm{g}}$ & $26.77^{\mathrm{i}}$ \\
\hline \multicolumn{10}{|c|}{ White egg } \\
\hline 2 & 19 & 20 & 23 & $155.00^{\mathrm{j}}$ & $155.00^{\mathrm{j}}$ & $155.00^{\mathrm{k}}$ & $36.07^{\mathrm{c}}$ & $36.58^{\mathrm{a}}$ & $37.03^{\mathrm{a}}$ \\
\hline 3 & 24 & 25 & 34 & $156.33^{\mathrm{j}}$ & $157.33^{\mathrm{i}}$ & $157.33^{\mathrm{j}}$ & $34.75^{\mathrm{d}}$ & $35.23^{b}$ & $33.31^{\mathrm{d}}$ \\
\hline 4 & 35 & 35 & 40 & $160.00^{\mathrm{i}}$ & $159.67^{\mathrm{h}}$ & $159.67^{\mathrm{i}}$ & $30.02^{\mathrm{f}}$ & $31.34^{\mathrm{e}}$ & $28.66^{\mathrm{h}}$ \\
\hline \multicolumn{10}{|c|}{ Whey protein } \\
\hline 3 & 25 & 31 & 35 & $180.33^{\mathrm{h}}$ & $180.33^{\mathrm{g}}$ & $181.32^{\mathrm{h}}$ & $38.77^{\mathrm{a}}$ & $35.07^{b}$ & $36.08^{b}$ \\
\hline 5 & 46 & 42 & 45 & $183.35^{\mathrm{g}}$ & $182.67^{\mathrm{f}}$ & $183.36^{\mathrm{g}}$ & $36.87^{\mathrm{b}}$ & $34.01^{\mathrm{c}}$ & $35.08^{\mathrm{c}}$ \\
\hline 7 & 60 & 66 & 63 & $185.67^{\mathrm{f}}$ & $184.33^{\mathrm{e}}$ & $185.68^{\mathrm{f}}$ & $33.10^{\mathrm{e}}$ & $31.14^{\mathrm{e}}$ & $30.93^{\mathrm{f}}$ \\
\hline
\end{tabular}

In a column, means having the same superscript letters are not significantly different at $5 \%$ level.

$\mathrm{MRP}=25 \mathrm{~g}$ millet $+75 \mathrm{~g}$ rice $+50 \mathrm{~g}$ potato; $\mathrm{FRP}=25 \mathrm{~g}$ flax seeds $+75 \mathrm{~g}$ rice $+50 \mathrm{~g}$ potato; $\mathrm{BCRP}=20 \mathrm{~g}$ rice bran $+30 \mathrm{~g}$ corn $+50 \mathrm{~g}$ rice $+50 \mathrm{~g}$ potato

\subsection{Effect of using improvers on water absorption of formula samples}

Water absorption is the amount of water taken up by flour to achieve the desired consistency and create a quality end-product. It is the optimal amount of water that can add to the dough before it becomes too sticky to process. Water absorption capacity is a critical function of protein in various food products like soups, dough, and baked products (Adeyeye and Aye, 1998).

The addition of hydrocolloids to dough improves its stability and quality criteria such as increased water absorption, specific loaf volume, and the viscoelastic properties (Tavakolipour and KalbasiAshtari 2007).

Table (3) presented the effect of adding different levels of improvers for gluten-free bread formulas on the water absorption capacity (WAC). The WAC ranged from $155.0 \%$ in MRP, FRP, and $\mathrm{BCRP}$ with $2 \mathrm{~g}$ white egg $/ 150 \mathrm{~g}$ formula to $271.36 \%$ in MRP with $7 \mathrm{~g}$ okra/ $150 \mathrm{~g}$ formula. The WAC of the gluten-free formula of MRP, FRP, and BCRP had a significant difference in different levels of improvers. The high WAC found in gluten-free formula flour with different levels of okra improver 
followed by xanthan and guar gum improvers with three levels. The lowest WAC between gluten-free bread flour samples found in white egg improvers and was ranged between 155 to $160 \%$.

The observed variation in the different formula of gluten-free flours may be due to differences in the chemical composition of flour sources and improvers. The WAC in gluten-free bread samples into the same improver couldn't be diverse. These results may be due to the constituents of composite bread which contain high fiber flour (millet, flaxseed, and rice bran), which absorb an approach amount of water.

In the contrast, the WAC of gluten bread formula affected with change improver and increased with increase different percentage of improvers. The results agree with Alamri (2014) who illustrated that water absorption was increased up to $4.4 \%$ due to okra extract. Okra-gum polysaccharides absorb water, therefore enhance bread quality. The competition is due to the ability of okra extract to absorb water faster than flour components.

\subsection{Effect of using improvers on weight loss of gluten-free flat bread samples}

Loaf weight is basically determined by the quantity of dough baked and the amount of moisture and carbon dioxide diffused out of the loaf during baking (Ragaee et al., 2006).

Loss in weight after baking of gluten-free flatbread samples was presented in Table 3.Among tested improvers; okra recorded the lowest weight loss of gluten-free bread after baking for all tested samples formula. Bread samples MRP, FRP, and BCRP with $7 \mathrm{~g}$ okra had the lowest loss weight after baking $(25.82,26.12$, and $25.88 \%$, respectively) compared to other bread samples. These results may be due to the high water holding capacity of okra compared to other improvers' in accordance with its chemical composition and high content of fiber (Adelakun and Oyelade, 2011).

On the other hand, the highest loss in gluten-free bread samples weight was noticed in MPR with $3 \mathrm{~g}$ whey protein $(38.77 \%)$, BCRP with $2 \mathrm{~g}$ white egg (37.03\%) followed by MRP with 5 gwhey protein $(36.87 \%)$. The loss in weight of gluten-free bread after baking was gradually decreasing by the increase of improvers levels. These results may be attributed to the higher ability of improvers to absorb and retains a lot of water. This observation may be due to the chemical composition of improvers (Table 2). These results were in accordance with Romanchuk-Cerpovicz et al., (2002).

From obtained results in Table 3, it can be concluded that gluten-free formula samples that had high viscosity and high WAC, have at the same time low baking weight loss. The obvious results showed that MRP, FRP, and BCRP with different levels of okra improver had high viscosity, high WAC, and low baking weight loss. In contrast MRP, FRP, and BCRP with different percentages of whey protein and white egg improvers had the lowest viscosity and WAC and the high baking weight loss.

\subsection{Effect of using improvers on up and down layer weight of gluten-free flat bread samples}

Loaf volume is affected by the quantity and quality of protein in the flour (Ragaee et al., 2006). Loaf weight is basically determined by the quantity of dough baked and the amount of moisture and carbon dioxide diffused out of the loaf during baking.

Results in Table 4 indicate that the okra improver had the highest of loaf weight, up and down layer loaf compared with other improvers followed by xanthan and guar gum mixture and whey protein improver. There is a significant increase in weight by increasing improver levels. This may be due to a high absorbance of water and viscoelastic characteristic of okra powder (Alamri, 2014). Okra contained high fiber, protein (Table 2), and mucilage content (Deogade et al., 2012). From data in Table 4, it could be concluded that the loaf weight, up and down layers of gluten-free flatbread samples were higher in the BCRP formula than in FRP and MRP formula. The up layer of different gluten-free flatbread formulas composite $40-45 \%$ of loaf weight, while down layer composite $55-60 \%$ of loaf weight. This means that there are noticeable separations in two layers between gluten-free flatbread formulas.

\section{Conclusion}

The results showed that using a specific mixture such as FRP, MRP, and BCRP along with different types of improvers resulted in the production of gluten-free flatbreads containing high levels of nutrients. Among the improvers used in this study, Okra at levels 3,5 and 7g improved the chemical and physical properties of the gluten-free flatbread compared to other improvers used. 
Table 4: Weight of up layer and down layer of MRP, FRP and BCRP gluten-free flat bread with different levels of improvers

\begin{tabular}{|c|c|c|c|c|c|c|c|c|c|}
\hline \multirow{2}{*}{$\begin{array}{c}\text { Improver } \\
\text { g/150g } \\
\text { formula }\end{array}$} & \multicolumn{3}{|c|}{ MRP } & \multicolumn{3}{|c|}{ FRP } & \multicolumn{3}{|c|}{ BCRP } \\
\hline & $\begin{array}{c}\text { Loaf } \\
\text { (g) }\end{array}$ & $\begin{array}{c}\text { up } \\
\text { layer(g) }\end{array}$ & $\begin{array}{c}\text { down } \\
\text { layer(g) }\end{array}$ & $\begin{array}{c}\text { Loaf } \\
(\mathrm{g})\end{array}$ & $\begin{array}{c}\text { up } \\
\text { layer(g) }\end{array}$ & $\begin{array}{c}\text { down } \\
\text { layer(g) }\end{array}$ & $\begin{array}{c}\text { loaf } \\
\text { (g) }\end{array}$ & $\begin{array}{c}\text { up } \\
\text { layer(g) }\end{array}$ & $\begin{array}{c}\text { down } \\
\text { layer(g) }\end{array}$ \\
\hline \multicolumn{10}{|c|}{ Okra } \\
\hline 3 & $46.27^{\mathrm{e}}$ & $20.04^{\mathrm{d}}$ & $26.23^{\text {ef }}$ & $48.03^{\mathrm{d}}$ & $22.33^{b}$ & $25.70^{\text {ef }}$ & $47.13^{f}$ & $21.82^{\mathrm{c}}$ & $25.31^{\mathrm{e}}$ \\
\hline 5 & $48.87^{\mathrm{c}}$ & $21.02^{\mathrm{c}}$ & $27.85^{\mathrm{bc}}$ & $49.07^{\mathrm{c}}$ & $23.35^{\mathrm{a}}$ & $25.72^{\text {ef }}$ & $49.70^{\mathrm{c}}$ & $22.64^{\mathrm{b}}$ & $27.06^{\mathrm{c}}$ \\
\hline 7 & $51.92^{\mathrm{a}}$ & $22.61^{\mathrm{a}}$ & $29.31^{\mathrm{a}}$ & $51.72^{\mathrm{a}}$ & $23.19^{\mathrm{a}}$ & $28.53^{\mathrm{b}}$ & $51.88^{\mathrm{a}}$ & $23.33^{\mathrm{a}}$ & $28.55^{\mathrm{b}}$ \\
\hline \multicolumn{10}{|c|}{ Xanthan \& guar gum } \\
\hline 0.8 & $45.09^{\mathrm{g}}$ & $18.88^{\mathrm{e}}$ & $26.21^{\text {ef }}$ & $46.01^{\mathrm{f}}$ & $19.43^{\mathrm{g}}$ & $26.25^{\mathrm{de}}$ & $48.95^{\mathrm{d}}$ & $20.90^{\mathrm{d}}$ & $28.05^{\mathrm{b}}$ \\
\hline 1.2 & $46.93^{\mathrm{d}}$ & $19.67^{\mathrm{d}}$ & $27.27^{\mathrm{cd}}$ & $47.16^{\mathrm{e}}$ & $20.36^{\mathrm{e}}$ & $26.80^{\mathrm{cd}}$ & $50.03^{\mathrm{c}}$ & $22.80^{\mathrm{ab}}$ & $27.23^{\mathrm{c}}$ \\
\hline 1.6 & $49.81^{\mathrm{b}}$ & $21.81^{\mathrm{b}}$ & $28.00^{\mathrm{b}}$ & $50.83^{\mathrm{b}}$ & $21.34^{\mathrm{c}}$ & $29.49^{\mathrm{a}}$ & $51.26^{\mathrm{b}}$ & $23.17^{\mathrm{ab}}$ & $28.09^{b}$ \\
\hline \multicolumn{10}{|c|}{ White egg } \\
\hline 2 & $44.75^{\mathrm{g}}$ & $18.88^{\mathrm{e}}$ & $25.87^{\mathrm{fg}}$ & $44.39^{\mathrm{h}}$ & $19.98^{\mathrm{ef}}$ & $24.74 \mathrm{~g}$ & $44.08^{\mathrm{i}}$ & $18.96^{\mathrm{fg}}$ & $25.12^{\mathrm{e}}$ \\
\hline 3 & $45.67^{\mathrm{f}}$ & $18.80^{\mathrm{e}}$ & $26.87^{\mathrm{de}}$ & $45.24^{\mathrm{g}}$ & $18.15^{\mathrm{h}}$ & $27.09^{c}$ & $46.68^{f}$ & $19.37^{\mathrm{f}}$ & $27.31^{\mathrm{c}}$ \\
\hline 4 & $48.99^{c}$ & $21.87^{\mathrm{b}}$ & $27.12^{\mathrm{d}}$ & $48.06^{\mathrm{d}}$ & $20.89^{d}$ & $27.17^{\mathrm{c}}$ & $49.94^{c}$ & $20.14^{e}$ & $29.80^{\mathrm{a}}$ \\
\hline \multicolumn{10}{|c|}{ Whey protein } \\
\hline 3 & $42.86^{\mathrm{i}}$ & $17.87^{\mathrm{f}}$ & $25.00^{\mathrm{h}}$ & $45.45^{\mathrm{g}}$ & $20.16^{\mathrm{ef}}$ & $25.29^{\mathrm{fg}}$ & $44.74^{\mathrm{h}}$ & $18.49^{\mathrm{g}}$ & $26.26^{\mathrm{d}}$ \\
\hline 5 & $44.19^{\mathrm{h}}$ & $18.86^{\mathrm{e}}$ & $25.33^{\mathrm{gh}}$ & $46.19^{f}$ & $19.96^{\mathrm{f}}$ & $26.23^{\mathrm{de}}$ & $45.44^{\mathrm{g}}$ & $20.85^{\mathrm{d}}$ & $24.59^{e}$ \\
\hline 7 & $46.83^{\mathrm{d}}$ & $19.93^{\mathrm{d}}$ & $26.90^{\mathrm{de}}$ & $48.20^{\mathrm{d}}$ & $20.04^{\mathrm{ef}}$ & $28.16^{\mathrm{b}}$ & $48.35^{\mathrm{e}}$ & $23.3^{\mathrm{a}}$ & $24.99^{e}$ \\
\hline
\end{tabular}

In a column, means having the same superscript letters are not significantly different at $5 \%$ level.

$\mathrm{MRP}=25 \mathrm{~g}$ millet $+75 \mathrm{~g}$ rice $+50 \mathrm{~g}$ potato; $\mathrm{FRP}=25 \mathrm{~g}$ flax seeds $+75 \mathrm{~g}$ rice $+50 \mathrm{~g}$ potato; $\mathrm{BCRP}=20 \mathrm{~g}$ rice bran $+30 \mathrm{~g}$ corn $+50 \mathrm{~g}$ rice $+50 \mathrm{~g}$ potato

\section{References}

Abd El-Kader, M.H., 2014. Festival bakery products using heat stabilized rice bran. Bulletin. Faculty of Agriculture, Cairo Univ., 65: 464-473.

Adelakun, O.E. and O.J. Oyelade, 2011. Potential use of okra seed (Abelmoschus esculrntus Moench) flour for food fortification and effects of processing. In: Flour and breads and their fortification in health and disease prevention, 205-212. Academic Press.

Adeyeye, E.I. and P.A. Aye, 1998. The effects of sample preparation on the proximate composition and the functional properties of the African yam bean (Sphenostylis stenocarpa Hochst ex A. Rich) flours. Note 1.La Rivista Italiana delle Sostanze Grasse, 75(5): 253-261.

Alamri, M.S., 2014. Okra-gum fortified bread: formulation and quality. Journal of Food Science and Technology, 51(10): 2370-2381.

Al-Dmoor, H.M., 2012. Flat bread: ingredients and fortification. Quality Assurance and Safety of Crops and Foods, 4 (1): 2-8.

Aly, M.M. and H.A. Seleem, 2015. Gluten-free flat bread and biscuits production by cassava, extruded soy protein and pumpkin powder. Food and Nutrition Sciences, 6 (07): 660-674.

Anton, A.A. and S.D. Artfield, 2008. Hydrocolloids in gluten-free breads: A review. International journal of food sciences and nutrition, 59 (1): 11-23.

A.O.A.C., 2010. Association of Official Analytical Chemists. Official Methods of Analysis. $18^{\text {th }}$ Edition, Washington, DC.

Arendt, E.K., L.A. Ryan, and F. Dal Bello, 2007. Impact of sourdough on the texture of bread. Food Microbiology, 24 (2): 165-174.

Arendt, E. and F. Dal Bello, 2008. Gluten-free cereal products and beverages. 1st ed. Elsevier Inc. DOI: https://doi.org/10.1016/B978-0-12-373739-7.X5001-1

Armitage, P., G. Berry, and J.N.S. Matthews, 1987. Comparison of several groups. Statistical methods in medical research, 4th ed., Blackwell Science, New York 186, 213. 
Bourekoua, H., U. Gawlik-Dziki, R. Różyło, M.N. Zidoune, and D. Dziki, 2021. Acerola fruit as a natural antioxidant ingredient for gluten-free bread: An approach to improve bread quality. Food Science and Technology International, 27(1): 13-21.

Brookfield Manual, 1998. Brookfield Manual Operating Instruction. Brookfield Engineering Laboratories Inc., Middleborough.

Burton, G.W., A.T. Wallace, and K.O. Rachie, 1972. Chemical composition and nutritive value of pearl millet (Pennisetum typhoides (Burm.) Stapf and EC Hubbard) grain 1. Crop Science, 12(2): 187-188.

Chudzikowski, R.J., 1971. Guar gum and its applications. J Soc Cosmet Chem 22:43-60

De la Hera, E., C.M. Rosell, and M. Gomez, 2014. Effect of water content and flour particle size on gluten-free bread quality and digestibility. Food Chemistry, 151: 526-531.

Deogade, U.M., V.N. Deshmukh, and D.M. Sakarkar, 2012. Natural gums and mucilage's in NDDS: applications and recent approaches. International Journal of Pharm Tech Research, 4(2): 799814.

El Khoury, Dalia, S. Balfour-Ducharme, and J.J., Iris, 2018. A Review on the gluten-free diet: Technological and Nutritional Challenges, Nutrients, 10, 1410

Gallagher, E., T.R. Gormley, and E.K. Arendt, 2003. Crust and crumb characteristics of gluten free breads. Journal of food engineering, 56 (2-3): 153-161.

Garcia-Ochoa, F., V.E. Santos, J.A. Casas, and E. Gomez, 2000. Xanthan gum: production, recovery, and properties. Biotechnology advances, 18(7): 549-579.

Gomez, M., A. Moraleja, B. Oliete, E. Ruiz, and P.A. Caballero, 2010. Effect of fibre size on the quality of fibre-enriched layer cake. LWT-Food Science and Technology 43(1): 33-38.

Hussain, S., F.M. Anjum, M.S. Alamri, A.A. Mohamed, and M. Nadeem, 2013. Functional flaxseed in baking. Quality Assurance and Safety of Crops and Foods, 5(4): 375-385.

Ijah, U.J.J., H.S. Auta, M.O. Aduloju, and S.A. Aransiola, 2014. Microbiological, nutritional, and sensory quality of bread produced from wheat and potato flour blends. International Journal of Food Science, 1-6.

Kahlon, T.S. and M.M. Chiu, 2012. Whole grain gluten-free flat breads. Cereal Foods World, 57 (1): 6-9.

Kahlon, T.S. and M.M. Chiu, 2014. Ancient whole grain gluten-free flatbreads. Food and Nutrition Sciences, 5, 1717-1724.

Ki-Won, S., K. Yong-Seok and C. Gap-Shik, 2006. Rheology of concentrated xanthan gum solutions: Steady shear flow behavior; Fibers and Polymers, 7(2): 129-138.

Kouassi, J.B., C. Massara, A.A. Monde, G.G. Tiahou, D.E. Sess, and E.T. Vama, 2013. Comparative study of proximate chemical composition of two varieties of okra dried, by two methods: sun and electric drying. American Journal of Bioscience, 1(4): 74-79.

Lemos, A.R., V.D. Capriles, M.E.M. Pinto e Silva, and J.A.G. Arêas, 2012. Effect of incorporation of amaranth on the physical properties and nutritional value of cheese bread. Food Science and Technology, 32 (3): 427-431.

Li, Q.Q., Y.S. Wang, H.H. Chen, S. Liu, and M. Li, 2017. Retardant effect of sodium alginate on the retrogradation properties of normal cornstarch and anti-retrogradation mechanism. Food Hydrocolloids, 69(1):1-9.

Majzoobi, M., A. Farahnaky, and S. Agah, 2011. Properties and shelf-life of part-and full-baked flat bread (Barbari) at ambient and frozen storage. Journal of Agricultural Science and Technology, 13: 1077-1090.

Maleki, M. and S. Daghir, 1967. Effect of baking on retention of thiamine, riboflavin, and niacin in Arabic bread. Cereal chemistry, 44(5): 483-487.

Marshall, K., 2004. Therapeutic applications of whey protein; a review. Alternative Medicine Review, Thorne Research, 9: 136-156.

Mastromatteo, M., S. Chillo, M. Iannetti, V. Civica, and M.A. DelNobile, 2011. Formulation optimisation of gluten-free functional spaghetti based on quinoa, maize and soy flours. Int. J. Food Sci. Technol., 46:1201-1208.

Mastromatteo, M., A. Danza, M. Guida, and M.A. Del Nobile, 2012. Formulation optimisation of vegetable flour-loaded functional bread Part I: screening of vegetable flours and structuring agents. International Journal of Food Science and Technology, 47(6): 1313-1320. 
Matos, M.E. and C.M. Rosell, 2015. A Review: Understanding Gluten Free Dough For Reaching Breads With Physical Quality And Nutritional Balance. Journal of the Science of Food and Agriculture 95(4) DOI: 10.1002/jsfa.6732Miñarro, B., Albanell, E., Aguilar, N., Guamis, B. and Capellas, M. (2012). Effect of legume flours on baking characteristics of gluten-free bread. Journal of Cereal Science, 56(2): 476-481.

Misra, A. and K. Kulshrestha, 2003. Potato flour incorporation in biscuit manufacture. Plant Foods for Human Nutrition, 58 (3): 1-9.

Morris D., 2003. Flax, a health and nutrition primer. Flax Council of Canada, 2-5.

Mudgil, D., S. Barak, and B.S. Khatkar, 2014. Guar gum: processing, properties and food applications. a review. Journal of Food Science and Technology, 51(3): 409-418.

Nascimento, A.C., C. Mota, I. Coelho, S. Gueifão, M. Santos, A.S. Matos, A. Gimenez, M. Lobo, N. Samman, and I. Castanheira, 2014. Characterisation of nutrient profile of quinoa (Chenopodium quinoa), amaranth (Amaranthus caudatus), and purple corn (Zea mays L.) consumed in the North of Argentina: Proximates, minerals and trace elements. Food Chemistry, 148: 420-426.

Nicolae, A., G.L. Radu, and N. Belc, 2016. Effect of sodium carboxymethylcellulose on gluten-free dough rheology. Journal of Food Engineering, 168: 16-19.

Noorlaila, A., A. SitiAziah, R. Asmeda, and A.R. Norizzah, 2015. Emulsifying properties of extracted okra (Abelmoschus esculentus L.) mucilage of different maturity index and its application in coconut milk emulsion. International Food Research Journal, 22(2):782-787.

Pszczola, D.E., 2012. The rise of gluten-free. Food Technology - Chicago, 66 (12): 55-66.

Ragaee, S., E.S.M. Abdel-Aal, and M. Noaman, 2006. Antioxidant activity and nutrient composition of selected cereals for food use. Food Chemistry, 98 (1): 32-38.

Ramadas, U. and R.N. Tharanathan, 1987. Functional properties of okra mucilage. Starch, 39(1):165167.

Romanchik-Cerpovicz, J.E., R.W. Tilmon, and K.A. Baldree, 2002. Moisture retention and consumer acceptability of chocolate bar cookies prepared with okra gum as a fat ingredient substitute. Journal of the American Dietetic Association, 102 (9): 1301-1303.

Romão, B., R.B.A. Botelho, E.R. Alencar, V.S.N. Silva, M.T.B. Pacheco, and R.P. Renata Puppin Zandonadi, 2020. Chemical composition and glycemic index of gluten-free bread commercialized in Brazil. Nutrients, 12 (8): 2234.

Różyło, R., D. Dziki, U. Gawlik-Dziki, G. Cacak-Pietrzak, A. Miś, and S. Rudy, 2015. Physical properties of gluten-free bread caused by water addition. International. Agrophysics., 29: 353364.

Sabanis, D. and C. Tzia, 2011. Effect of hydrocolloids on selected properties of gluten-free dough and bread. Food Science and Technology International, 17 (4): 279-291.

Saha, S., A. Gupta, S.R.K. Singh, N. Bharti, K.P. Singh, V. Mahajan, and H.S. Gupta, 2011. Compositional and varietal influence of finger millet flour on rheological properties of dough and quality of biscuit. LWT - Food Science and Technology, 44 (3): 616-621.

Sayed, H.S., A.M. Sakr, and N.M.M. Hassan, 2016. Effect of Pseudo cereal flours on technological, chemical and sensory properties of Panbread. World Journal of Dairy and Food Sciences, 11 (1): 10-17.

Schober, T., S. Bean, D. Boyle, and S. Park, 2008. Improved viscoelastic zein-starch doughs for leavened gluten-free breads: Their rheology and microstructure. J. Cereal Sci., 48, 755-767.

Schoenlechner, R., M. Szatmari, A. Bagdi, and S. Tömösközi, 2013. Optimization of bread quality produced from wheat and proso millet (Panicum miliaceum L.) by adding emulsifiers, transglutaminase and xylanase. LWT-Food Science and Technology, 51 (1): 361-366.

Shahzad, S.A., S. Hussain, M.S. Alamri, A.A. Mohamed, A.S. Ahmed, M.A. Ibraheem, and A. Akram, 2019. Use of hydrocolloid gums to modify the pasting, thermal, rheological, and textural properties of sweet potato starch. International Journal of Polymer Science, 19(1):1-11.

Singh, K.P., H.N. Mishra, and S. Saha, 2010. Moisture-dependent properties of barnyard millet grain and kernel. Journal of Food Engineering, 96 (4): 598-606.

Singh, K.K., D. Mridula, J. Rehal, and P. Barnwal, 2011. Flaxseed: a potential source of food, feed and fiber. Critical reviews in food science and nutrition, 51(3): 210-222.

Singh, P. and S. Srivastava, 2006. Nutritional composition of sixteen new varieties of fingermillet. J. Community Mobilization Sustainable Dev., 1(2): 81-84. 
Sosulski, F., E.S. Humbert, K. Bui, and J.D. Jones, 1976. Functional Propreties of Rapeseed Flours, Concentrates and Isolate. Journal of Food Science, 41 (6): 1349-1352.

Sridhar, R., and G. Lakshminarayana, 1994. Content of total lipids and lipid classes and composition of fatty acids in small millets: foxtail (Setaria italica), proso (Panicum miliaceum), and finger (Eleusine coracana). Cereal Chem., 71 (4): 355-358.

Steel, R.G.D. and J.H. Torrie, 1980. Principles and procedures of statistics, a biometrical approach (2nd Ed.). McGraw-Hill Kogakusha, Ltd.

Suma, P.F., and A. Urooj, 2014. Nutrients, antinutrients and bioaccessible mineral content (in vitro) of pearl millet as influenced by milling. Journal Food Science and Technology, 51(4): 756-761.

Sze, W.K., N. Huda, M. Dewi, and H. Hashim, 2018. Physicochemical properties of egg white powder from eggs of different types of bird. International Journal on Advanced Science, Engineering and Information Technology, 8(2): 384-389.

Tavakolipour, H. and A.H.M.A.D. Kalbasi-Ashtari, 2007. Influence of gums on dough properties and flat bread quality of two persian wheat varieties. Journal of Food Process Engineering, 30 (1): 74-87.

Tsatsaragkou, K., G. Gounaropoulos, and I. Mandala, 2014. Development of gluten free bread containing carob flour and resistant starch. Lebensmittel-Wissenscha Technologie, 58(1): 124129.

Wronkowska, M., M. Haros, and M. Soral-Śmietana, 2013. Effect of Starch Substitution by Buckwheat Flour on Gluten-Free Bread Quality. Food Bioprocess Technology, 6 (7):1820-1827.

Yadav, S.P., N.K. Sharma, C. Liu, L. Dong, T. Li, and A. Swaroop, 2016. Centrosomal protein CP110 controls maturation of the mother centriole during cilia biogenesis. Development, 143(9): 14911501.

Zahran, M.M., K.B. Abdel-Aziz, A. Abdel-Raof, and E.M. Nahas, 2005. The effect of subacute doses of organophosphorus pesticide, Nuvacron, on the biochemical and cytogenetic parameters of mice and their embryos. Research Journal of Agriculture and Biological Sciences, 1(3): 277283. 